\title{
Sustainable Production Systems for Cynodon Species in the Subtropics and Tropics
}

\author{
Lynn E. Sollenberger
}

\footnotetext{
1 Faculdade de Ciências Agrárias e Veterinárias - FCAVJ/UNESP, CEP: 148894-900 - Jaboticabal/SP - Brasil.

2 Faculdade de Zootecnia e Engenharia de Alimentos - FZEA/USP, CEP: 13635-900 - Pirassununga/SP - Brasil.

3 Faculdade de Medicina Veterinária e Zootecnia - FMVZ/USP, CEP: 13635-900 - Pirassununga/SP - Brasil.
}

Key Words: Bermudagrass, Defoliation Management, Grassland Ecosystems, Integrated Crop-Livestock Systems, Nutrient Cycling, Stargrass

\section{Introduction}

A comprehensive discussion of grass species in the genus Cynodon is beyond the scope of this review. Such a comprehensive review has been published by Taliaferro et al. (2004). The primary focus of this review will be sustainable production practices for Cynodon grasslands. In this context, sustainable grassland production systems are defined as those that over the long term enhance environmental quality and the resource base of the system while providing human food needs in an economically viable manner and one that enhances the quality of life for both producers and consumers (Stewart et al., 1991). Preceding this discussion will be brief coverage of the taxonomy and morphology of Cynodon spp. and their contribution to production systems. The focus on sustainable systems will be organized around three main themes: nutrients, grazing management, and integrated crop-livestock systems.

\section{Taxonomy and morphology}

Bermudagrass [Cynodon dactylon (L.) Pers.] and stargrass (Cynodon nlemfuensis Vanderyst) are the two most important forage grasses in the genus Cynodon. Stargrass is the name used for the robust, nonrhizomatous type native to East Africa, while bermudagrass refers to rhizomatous forms (Harlan, 1970). Recent publications have used the common name stargrass for C. aethiopicus W.D. Clayton \& J.R. Harlan, C. plectostachyus (K. Schu.) Pilg., and C. nlemfuensis (Taliaferro et al., 2004). There has been considerable taxonomic confusion in the genus, with literature before 1970 calling the East African forms $C$. plectostachyus or $C$. dactylon, when they should have been classified as $C$. aethiopicus or $C$. nlemfuensis. Most tropical Africa grazing studies carried out before 1970 that referred to $C$. dactylon were likely performed using $C$. nlemfuensis. In addition, the naming of some Cynodon cultivars has created confusion. 'Tifton 85' "bermudagrass" is an interspecific hybrid (C. spp.) between a true bermudagrass ( $C$. dactylon) and 'Tifton 68' "bermudagrass"; the latter is actually a stargrass ( $C$. nlemfuensis) (Burton and Monson, 1984). A detailed description of Cynodon species and taxonomic varieties within those species was provided by Taliaferro et al. (2004).

Bermudagrass is particularly abundant and diverse in Africa extending to Southeast Asia, suggesting the center of origin is in this broad geographic area (Taliaferro et al., 2004). Bermudagrass is distributed widely geographically and varies from small types that grow to a height of only 15 to $20 \mathrm{~cm}$ to large types that grow to $1 \mathrm{~m}$ or more. Bermudagrass typically has both stolons and rhizomes. It is best adapted to moderately to well-drained soils, is considered relatively drought tolerant, and is adapted from the tropics to the cooler subtropics and milder temperate areas, where frosts and freezes are numerous during winter.

Stargrasses are indigenous to tropical Africa, but they have been exported throughout the tropics and subtropics (Taliaferro et al., 2004). They often have 
larger leaves and stems than bermudagrass. They spread aggressively by stolons that may grow up to $10 \mathrm{~m}$ in length and form roots and shoots from the nodes, but they lack rhizomes. Stargrass is best adapted to environments with $>800 \mathrm{~mm}$ of annual precipitation and temperatures that do not fall below $\quad-6^{\circ} \mathrm{C}$ (Mislevy et al., 1989).

\section{Contribution to production systems}

Bermudagrass and stargrass are among the group of most important $\mathrm{C}_{4}$ perennial grasses used for pasture and hay production in warm climates. In the USA, bermudagrass is grown on approximately 12 million ha and is the most widely used perennial forage in the southern states (Redfearn and Nelson, 2003). Stargrass, because of its lack of cold tolerance, is limited to about 50,000 ha in South Florida. Bermudagrass is grown widely in tropical and subtropical regions throughout the world including Africa, Asia, Australia, and the Americas. Stargrass is more important outside the USA and contributes significantly in Central and South America, tropical Africa, and the Caribbean.

The popularity of bermudagrass and stargrass is predicated upon their ease of establishment, high biomass production potential, and palatability. Bermudagrasses are generally more tolerant of heavy grazing than stargrasses because bermudagrasses have rhizomes and associated protected bud sites and reserve storage. Sustained productivity of stargrass requires greater attention to grazing management because stem bases and stolons are important for reserve storage and can be removed under frequent, close defoliation (Pitman, 1991). Both grasses require significant soil nutrient inputs to perform at optimal levels and persist long term. Thus, as the cost of $\mathrm{N}$ fertilizer increases, it is important to consider the sustainability of current production systems using these grasses and to consider the merits of greater integration of forage-livestock and crop production systems.

\section{Grassland sustainability}

It has been estimated that in tropical regions of Brazil there are at least 40 million ha of degraded pastures; areas that have been described as supporting a low stocking rate, having low plant cover, and being invaded by non-palatable native species (Boddey et al., 2004). These authors attribute pasture degradation primarily to two factors, lack of maintenance fertilizer and excessively high animal stocking rates. During the remainder of the review, sustainability of Cynodon spp. grasslands will be explored within the context of nutrient dynamics, grazing management, and integration of crop and livestock systems.

\section{Nutrient Dynamics}

In grassland agroecosystems, nutrients needed for plant growth are provided by fertilizers and by microbially mediated breakdown of dead plant tissue, livestock excreta, soil organic matter, and geochemically bound mineral forms. This entire system must be considered when determining appropriate fertilizer application rates because fertilizer additions are simply one input in a system of inputs, outputs, and fluxes in the ecosystem (Wedin and Russelle, 2007). In this section of the review, the role of fertilizers, legumes, decaying plant litter, and excreta as nutrient sources for Cynodon spp. grasslands will be discussed.

\section{Fertilization}

Nitrogen fertilizer generally has the greatest influence of any fertilizer nutrient on biomass yield and influences the amount of other nutrients needed to sustain production (Taliaferro et al., 2004). Thus the focus of the discussion on fertilization will be nitrogen. From a sustainability perspective, nitrogen fertilizer can arrest the process of grassland degradation and ensure greater persistence, but its use has become or is becoming cost prohibitive in many pasture-based production systems.

There is extensive literature documenting the responsiveness of bermudagrass and stargrass herbage accumulation to nitrogen. Early studies conducted by Prine and Burton (1956) in Georgia, USA showed that increasing nitrogen rate from 0 to $300 \mathrm{~kg} / \mathrm{ha} /$ year increased yield of Coastal bermudagrass cut every $4 \mathrm{wk}$ from 2.7 to 17.9 tons/ha. In Florida, USA, Vendramini et al. (in review) showed that Tifton 85 herbage accumulation increased from 1.6 to 2.6 tons/ha as nitrogen rate per 4 -wk growth period increased from 0 to $80 \mathrm{~kg} / \mathrm{h}$. Throughout a grazing season with herbage 
allowance maintained at $\sim 1.0 \mathrm{~kg}$ forage dry matter $\mathrm{kg}^{-1}$ animal liveweight, this increase in herbage accumulation would allow stocking rates to increase from 3.5 to 5.7 animal units (AU) ha $^{-1}$, where an animal unit is $500 \mathrm{~kg}$ liveweight. Greater tiller density and tiller mass explained greater herbage accumulation of Tifton 85 as nitrogen rates increased (Premazzi et al., 2003).

Stargrass has shown linear increases in herbage accumulation up to approximately $450 \mathrm{~kg}$ nitrogen fertilizer/ha in Puerto Rico and Florida (Caro-Costas et al., 1972; Mislevy and Martin, 1998). In Jamaica, increasing nitrogen rate from 112 to $336 \mathrm{~kg} / \mathrm{ha}$ during a 290-day experimental period increased herbage accumulation from 20 to 24.1 tons/ha in grazed stargrass pastures (Hernández Garay et al., 2004a).

Nutritive value and in some cases individual animal performance on bermudagrasses and stargrasses has responded to nitrogen. Increasing nitrogen rate from 0 to $80 \mathrm{~kg} /$ ha per 4 -wk regrowth period in Florida was accompanied by greater Tifton 85 herbage crude protein (11.5 to $13.5 \%$ ) and in vitro digestibility (48 to 53\%; Vendramini et al., in review). Levels of rapidly degradable crude protein Fraction A in Tifton 85 (averaging $356 \mathrm{~g} / \mathrm{kg}$ of crude protein) were not affected by nitrogen fertilization ranging from 0 to $80 \mathrm{~kg} / \mathrm{ha}$ per 4-wk regrowth period (Vendramini et al., 2008). There was, however, a linear increase in potentially degradable Fraction B (from 330 to 455 g/kg crude protein) and a linear decrease in undegradable fraction C (from 283 to $208 \mathrm{~g} / \mathrm{kg}$ crude protein) as nitrogen fertilization increased. Thus, not only is total crude protein lower when nitrogen fertilizer rates are low, but rumen-degradable protein in Tifton 85 is also reduced, potentially limiting performance of ruminants with high crude protein requirements. To address this limitation, the most easily implemented options to increase protein availability in the rumen include use of supplement containing rumen-degradable protein, nitrogen fertilization of forage, or a shorter regrowth interval between grazings.

In Jamaica, stargrass herbage crude protein and in vitro digestibility increased as nitrogen rate increased from 112 to $336 \mathrm{~kg} / \mathrm{ha}$ at all but the greatest stocking rate (Hernández Garay et al., 2004a; Tables 1 and 2). In the same study, increasing nitrogen rate from 112 to $336 \mathrm{~kg} / \mathrm{ha}$ resulted in relatively small but consistently linear increases in yearling bull average daily gain $(0.46$ to $0.53 \mathrm{~kg} / \mathrm{ha}$ in Year 1 and 0.47 to 0.54 in Year 2). The effect of nitrogen rate on liveweight gain/ha was dependent upon stocking rate with very little impact at 2.5 head/ha but significant impact at 5 and 7.5 head/ha, when the additional herbage accumulation provided by the nitrogen applied was important (Fig. 1).

\section{Use of Legumes}

Legumes with their associated nitrogen fixation have long been recognized as having significant potential to contribute to sustainable animal production systems in the tropics (Shelton et al., 2005). This potential has largely been realized in temperate grasslands, but in warm climates around the world legume adoption has been only minimally successful (Peters and Lascano, 2003; Sollenberger and Collins, 2003). Pengelly et al. (2003) concluded that despite 50 years of investment in forage research in the tropics, forage legume adoption has been relatively poor across a range of farming systems. It has been suggested that this may be due in part to attempts by scientists and grassland farmers to directly transfer to warm climates the methodologies that have been successful in temperate areas, in particular grasses and legumes planted together and growing in association (Shelton et al., 2005). This model may not be successful in warm climates owing to differences in grazing tolerance between warm-climate grasses and legumes (Kretschmer and Pitman, 2001) and to widely varying competitive ability between vigorous $\mathrm{C}_{4}$ grasses and the $\mathrm{C}_{3}$ legumes (Sollenberger and Collins, 2003).

Bermudagrass and stargrass production systems have typically depended upon $\mathrm{N}$ fertilizer, and Cynodon spp.-legume research, particularly with warm-season or tropical legumes has been limited. Legume success in association with Cynodon spp. is likely to be affected negatively by the vigorous growth and strongly stoloniferous growth habit of these grasses. Research conducted in Mexico showed that Desmanthus bicornatus and $D$. pubescens can be established in 'Tifton 68' "bermudagrass" (actually a stargrass) by seeding in rows that were previously treated with glyphosate to control grass competition (Zarate et al., 2004). They found that a glyphosate band of $15 \mathrm{~cm}$ was sufficient to allow maximum legume emergence and seedling survival through 1.5 years following planting. 
There was no information provided as to whether these pastures were grazed during the time period of establishment, so persistence of this legume is uncertain.

Much of the legume work in bermudagrass was conducted in the southern USA and involved overseeding the grass with cool-season legumes. In the northern range of bermudagrass adaptation, alfalfa tended to out-compete bermudagrass and cause stand depletion over time (Stringer et al., 1994). In the southern range of adaptation, Burton and DeVane (1992) stated that "attempts to grow legumes with Coastal bermudagrass on the southern Coastal Plain have enjoyed few successes and many failures.” They attributed this to soil acidity, lack of fertility, and limited ability to hold water. Studying a group of seven cool-season legumes, they found that white clover (Trifolium repens) was most successful. Positive results with overseeding red (T. pretense) and crimson ( $T$. incarnatum) clovers into Tifton 85 bermudagrass have been achieved in Florida (Reis et al., 2001).

A warm-season legume-bermudagrass association that has proven successful is rhizoma peanut (Arachis glabrata)-common bermudagrass. In Florida, peanut cvs. Arbrook and Florigraze were stocked continuously during 3 years with Holstein heifers at a rate of 2.7 AU/ha (Hernández Garay et al., 2004b). The more prostrate-growing Florigraze maintained a botanical composition of 90,89 , and $87 \%$ of total herbage mass during the 3 years; however, percentage of the more upright-growing Arbrook declined from 89 in Year 1, to 82 and 66 in Years 2 and 3, respectively. This occurred due to the more open canopy of Arbrook which allowed a better light environment for common bermudagrass and greater competition to the legume. Thus, there are examples of successful associations of legumes and Cynodon spp., but they have been few in number and are limited to situations when the most competitive of legumes are used and when $\mathrm{N}$ fertilizer is limited or not applied.

Because of the record prices of oil and its impact on $\mathrm{N}$ fertilizer costs, there is likely to be greater emphasis on legumes in the future. Recent legume success stories, including leucaena (Leucaena leucocephala) in Australia and pinto peanut (Arachis pintoi) in Brazil (Mullen et al., 2005; Valentim and Andrade, 2005) give some reason for hope. Novel approaches for use of legumes with grasses also have emerged (Chapman et al., 2006). In Queensland, Australia beef cattle fattening systems have made excellent use of leucaena seeded in a hedgerow pattern into a prepared seedbed (Mullen et al., 2005). After legume plants were sufficiently established, grasses were seeded between the leucaena hedges, thus allowing the legume time to gain competitive advantage by virtue of its superior height. Another alternative practice receiving consideration in a number of environments is planting monoculture strips of two or more species within a given pasture unit (Rutter et al., 2003). Chapman et al. (2007) argue that use of these "spatially separate swards" allows management to address species-specific constraints including weed control and soil fertility. The ability to tailor management to the legume may provide the additional impetus needed to increase stand longevity and maintain legume presence in the production system. There is limited information on use of spatially separate swards in warm climates, but the lack of successful grass-legume mixtures suggests that it merits attention.

\section{Litter Dynamics}

Conservative stocking decisions are required to allow standing forage to accumulate for use during prolonged cool or dry seasons, and the result is that many warm-climate grasslands are underutilized during the period of maximum growth. Under these conditions, senescing plant material or "litter" accumulates and constitutes an important nitrogen pool (Dubeux et al., 2006a). With increasing stocking rate and forage utilization rate, the relative importance of above-ground litter diminishes because a greater proportion of nutrients are returned via excreta (Thomas, 1992).

Litter of $\mathrm{C}_{4}$ grasses often is low in quality and may result in nitrogen immobilization (Fisher et al., 1997) which aggravates the existing nitrogen shortage in low-input systems (Rezende et al., 1999). The litter pool, particularly due to its low quality in warm-climate grasslands, acts as a sink of available soil nitrogen (Myers et al., 1986; Thomas and Asakawa, 1993). Litter is a very important nitrogen pool, because along with the soil microbiota it constitutes the link between nitrogen in metabolically active plant tissues and $\mathrm{N}$ available for plant uptake (Thomas and Asakawa, 
1993). Excluding soil and atmospheric nitrogen, Robertson et al. (1993) estimated that in green panic (Panicum maximum Jacq. var. trichoglume Robyns) pastures, 30 to $50 \%$ of all nitrogen in the ecosystem was in plant litter and senesced tissues, i.e., currently unavailable for plant uptake.

The quality of forage plant litter can be affected by management, particularly nitrogen fertilization and extent of forage utilization (Dubeux et al., 2007). Ongoing studies in Florida are assessing the impact of nitrogen fertilization (50, 150 and $250 \mathrm{~kg} \mathrm{~N} / \mathrm{ha} /$ year) and postgraze stubble height (grazed to 8-, 16-, or 24cm stubble every 28 days) of Tifton 85 pastures on litter production, composition, and degradation characteristics. Preliminary data from these studies (Liu et al., University of Florida, personal communication) show that during a 128-day field incubation period dry matter loss was 357, 439, and $479 \mathrm{~g} / \mathrm{kg}$ for litter from bermudagrass pastures fertilized with 50, 150, and 250 kg nitrogen/ha/year (Fig. 2). These data concur with those for other $\mathrm{C}_{4}$ grasses that greater nitrogen fertilization increases litter quality and the rate of degradation (Dubeux et al., 2006b). The effect of degree of utilization was less pronounced than the nitrogen fertilizer effect, and dry matter loss was 409, 486, and $479 \mathrm{~g} / \mathrm{kg}$ for pastures grazed to 8,16 , and 24-cm stubble heights (Fig. 2). Based on assumptions that lesser utilization of pastures results in accumulation of low quality litter, this response is contrary to what was expected. One factor that may be involved is that the litter used for degradation studies in these experiments was dead material that had not yet dropped to the soil surface, thus the chemical characteristics are likely much different than in deposited litter.

A reasonable question is whether the presence of legume and its higher quality plant litter is sufficient to stem the tide of grassland degradation in low-input, warm-climate grasslands. In Colombia, Thomas and Asakawa (1993) reported that available monthly nitrogen from litter decomposition was three to six times greater for the legumes Centrosema acutifolium and Stylosanthes capitata, respectively, than for four tropical grasses. They calculated that legume litter provided from 20 to as high as $76 \%$ of pasture nitrogen requirements. In Brazil, including Desmodium ovalifolium (legume) in Brachiaria spp. pastures increased nitrogen recycled through the litter pathway by $50 \%$ (Boddey et al., 2005). These studies provide evidence that if management practices are developed to allow legumes to persist in warm-climate grasslands their presence will have a major positive effect on nitrogen availability within the system.

\section{Excreta}

With increasing stocking rate and forage utilization rate, the relative importance of above-ground litter diminishes because a greater proportion of nutrients are returned via excreta (Thomas, 1992). Herbivores accelerate $\mathrm{N}$ cycling through decomposition and excretion of plant nutrients and through the effects of grazing and excreta on soil biota (Bardgett and Wardle, 2003). Retention of consumed nitrogen in ruminant animal products is low, ranging from 5 to $30 \%$, thus nitrogen return to the grassland via animal excreta is a major component of the nutrient cycle (Rotz et al., 2005). Recovery of this nitrogen by plants varies greatly due to the heterogeneous distribution of excreta and the potentially wide ranges in nitrogen losses due to leaching, volatilization, denitrification, and immobilization (Mathews et al., 2004). Because utilization of nutrients by livestock converts them to forms that are more susceptible to loss, presence (vs. absence) of cattle in a grassland and higher (vs. lower) stocking rates have been associated with accelerated rates of pasture degradation (Castilla et al., 1995; Boddey et al., 2004) in some environments. Assessing this situation, Shelton et al. (2005) concluded that "the broad-scale grazed tropical grass pastures in Australia, southern USA, and Central and South America will neither be productive or stable unless their nitrogen nutrition is maintained. Declining nitrogen status leads to reduced productivity, reduced pasture vigor, and weed invasion.” Maintaining nitrogen nutrition is a difficult challenge currently and threatens to become much more difficult as cost of nitrogen fertilizer soars above levels at which it can be applied economically.

\section{Grazing Management}

The objectives of grazing management may include maximization of forage production and optimization of forage use efficiency (Parsons et al., 1988), persistence of desired species, and a high level of production per animal and per unit land area. These outcomes must be achieved without exceeding the managerial skill or risk tolerance of the grazier, while 
providing acceptable economic return and maintaining environmental quality. Manipulation of grazing intensity, method, and timing is the primary means used to achieve the desired canopy characteristics.

In this discussion, grazing intensity is considered to be a measure of the severity of grazing. Specific measures of grazing intensity include forage mass, canopy height (continuous stocking) or post-grazing stubble height (rotational stocking) of the pasture, forage allowance (kg forage mass per animal unit or per $\mathrm{kg}$ of animal live weight), grazing pressure (animal units $\mathrm{kg}^{-1}$ of forage mass), or stocking rate (animal units $\mathrm{ha}^{-1}$ ). These terms were defined by the Forage and Grazing Terminology Committee (1992).

The selection of a grazing intensity is more important than any other single grazing management decision (Jones and Jones, 1997). This is due to its prominent role in determining forage plant productivity and persistence (Chacon and Stobbs, 1976), animal performance (Humphreys, 1991; Newman et al., 2002), and the profitability of the grazing operation. Appreciation of the relationship of grazing intensity with pasture and animal performance is crucial for the long-term success of the forage-livestock enterprise (Walker, 1995).

Forage species respond differently to grazing intensity and the response to grazing a particular species leniently or severely cannot be extrapolated to other species. Even the same forage under the same grazing regime may respond differently under various environments (Matches, 1992; Bryan et al., 2000). Further, the response to grazing intensity can be made more or less severe by the associated grazing frequency. This phenomenon is illustrated frequently in grazing management research by the occurrence of grazing intensity by frequency interactions (Ortega et al., 1992; Liu et al., 2008). Because these factors interact so strongly, the discussion that follows is organized by plant species and not by frequency and intensity. For the two species discussed, the effects of grazing intensity and frequency and their interaction will be explored.

\section{Stargrass}

Long-term use of high grazing intensity has proven to be unacceptable for stargrasses (Pitman, 1991). Stargrass pastures were stocked at 2, 4, and 6 yearling steers/ha (285 kg initial weight) during 2 years. Average daily gain decreased from 0.80 to $0.56 \mathrm{~kg} /$ day as stocking rate increased from 2 to 6 steers/ha, but gain/ha increased from 173 to $362 \mathrm{~kg}$. However, 2 year of grazing at the high stocking rate resulted in sufficient loss of stargrass stand and invasion by weedy species that this treatment had to be discontinued.

The responses of three stargrasses (Florico, Florona, and Ona) to treatment combinations of grazing intensity (stubble heights of 5-25 cm) and frequency (pastures grazed at plant heights above stubble ranging from 0-60 cm) were assessed in Florida (Mislevy et al., 1989). Stubble height was the primary factor that affected persistence of stargrass. Allowing a postgraze stubble height of $15-25 \mathrm{~cm}$ resulted in lowest weed cover for all cultivars. Of the three cultivars, Florico was markedly less persistent than the others under frequent, close grazing. Herbage accumulation was greatest when plant height at initiation of grazing was 45-60 cm greater than the target postgraze stubble height. Only slight reductions in accumulation occurred when height at initiation was $15-45 \mathrm{~cm}$ above the target stubble so long as stubble height was greater than 15 $\mathrm{cm}$. Thus, stargrass persistence and herbage accumulation in Florida are quite responsive to grazing intensity, and choice of grazing intensity is a primary determinant of its long-term success.

Stargrass nutritive value is also affected by stocking rate. Crude protein and digestibility of handplucked stargrass herbage increased as stocking rate increased across a range of pasture nitrogen fertilizer rates in Jamaica (Tables 1 and 2; Hernández Garay et al., 2004a). Greater nutritive value with increasing grazing intensity was attributed to greater utilization of more heavily stocked pastures and an associated reduction in the average maturity of the herbage mass. In that experiment, animal daily gains decreased with increasing stocking rate, thus greater nutritive value at high stocking rates did not translate into greater animal gains because greater stocking rate was associated with inadequate quantity of forage.

\section{Bermudagrass}

Mandebvu et al. (1999) carried out a comprehensive comparison of defoliation frequency effects on Tifton 85 and Coastal bermudagrass nutritive value. Dry matter yields increased with increasing regrowth interval for both cultivars, and Tifton 85 outyielded Coastal by $34 \%$. In vitro digestibility of Tifton 85 was greater than Coastal in spite of Coastal 
herbage being lower in neutral and acid detergent fiber. This was attributed in part to greater lignin and etherlinked ferulic acid concentration in Coastal than Tifton 85, factors that contributed to lesser neutral and acid detergent fiber digestibility for Coastal than Tifton 85.

Mislevy and Martin (1998) evaluated herbage accumulation and persistence responses of two bermudagrasses (Tifton 85 and Florakirk) and two stargrasses (Florona and Florico) to defoliation frequency in South Florida. The herbage accumulation response was similar among grasses, and it increased linearly as length of regrowth period increased (Table 3). Of perhaps greatest significance among these data are the differences in patterns of response across years. In particular, the response across years is strikingly consistent when grazing occurred every 6 weeks, but when grazing occurred every 2 weeks there is a pattern of decline over time suggesting loss of stand vigor. Florico stargrass pastures defoliated every 2 weeks had $36 \%$ cover by common bermudagrass after 3 years of grazing.

Callie bermudagrass was grazed by dairy replacement heifers in northern Florida (Mathews et al., 1994). Treatments were three grazing methods including rotational stocking with a long grazing period (three paddocks in the pasture with cattle moved to a new paddock every 10 to 14 days; target postgraze stubble height of $15 \mathrm{~cm}$ ), rotational stocking with a short grazing period (15 paddocks with cattle moved to a new paddock every 1.5 to 2.5 days; target postgraze stubble height of $15 \mathrm{~cm}$ ), and continuous stocking (grazed as the same stocking rate as long grazing period rotational). The most striking effect of the grazing treatments was the decline in percentage Callie bermudagrass in the pastures that were continuously stocked (90 to $62 \%$, change of -28 ), while the rotational pastures had declines of 4 to 7 percentage units (Table 4). The component of the pastures that increased over time was primarily common bermudagrass. Common is a low-growing species that is shaded during a significant portion of the regrowth period when associated with the taller growing Callie under rotational stocking. Continuous stocking results in regular removal of Callie herbage, diminishing shading of the lower-growing common, and allowing it to be more competitive with Callie. Interestingly, in Year 1 animals on continous pastures had greater average daily gain than those on rotationally stocked pastures; however, in Year 2 there was no difference. It is possible that the increasing proportion of the lower quality common bermudagrass by Year 2 caused the different pattern of animal gain response between years, illustrating the impact of choice of grazing method for some associations of bermudagrass is a component.

Grazing intensity and frequency effects on Tifton 85 and Florakirk bermudagrasses were assessed in Florida. When Tifton 85 was grazed to an 8-cm stubble, herbage accumulation was less when interval between grazings was 14 days (11.4 t/ha) than when regrowth interval was 28 days ( $15.4 \mathrm{t} / \mathrm{ha}$; Table 5 ; Liu et al., 2008). In contrast, taller stubble heights typically resulted in greater herbage accumulation when regrowth interval was short. Herbage digestibility decreased linearly from 630 to $601 \mathrm{~g} / \mathrm{kg}$ as regrowth interval increased from 14 to 28 days, while crude protein was always greatest for shorter (139 $\mathrm{g} / \mathrm{kg}$ for 14 days) vs. longer regrowth intervals (116 g/kg for 28 days) and generally for shorter $(135 \mathrm{~g} / \mathrm{kg}$ for $8 \mathrm{~cm})$ vs. taller stubble heights (126 g/kg for $24 \mathrm{~cm}$ ).

Florakirk bermudagrass was grazed every 7,21 , and 35 days to postgraze stubble heights of 8,16 , and $24 \mathrm{~cm}$ (Pedreira et al., 2000). During 2 years of grazing, botanical composition was never below 96\%. Florakirk responded to close, frequent grazing by assuming a prostrate growth habit and tillering profusely, allowing significant leaf area to remain after grazing and reducing the need for reserves to support regrowth. The authors concluded that because persistence was not affected greatly by choice of rotational stocking treatment, management recommendations should be based on large part on productivity and nutritive value. In a companion study with the same treatments, grazing approximately every 14 days to a stubble height of 20 $\mathrm{cm}$ resulted in near maximum levels of both herbage accumulation and nutritive value (Pedreira et al., 1999).

Mechanisms of response to defoliation have been assessed in studies of bermudagrass tiller dynamics. Defoliated grasses exhibit tiller mass/density compensation in response to grazing intensity and this self-regulation can be considered a means by which pastures regulate leaf area index in response to changes in grazing intensity (Matthew et al., 1995). There are limits to this compensation, or phenotypic plasticity, associated with particular plant species and environments 
(Chapman and Lemaire, 1993). Tifton 85 bermudagrass swards were continuously stocked by sheep to maintain sward heights of $5,10,15$, and $20 \mathrm{~cm}$ during one growing season in Piracicaba, Sao Paulo, Brazil (Sbrissia et al., 2003). For observations made during the early to midsummer, tiller population density decreased with increasing sward height; however, responses were much less consistent in autumn and early winter (Table 6). Tiller mass increased by nearly a factor of six from the shortest to the tallest sward height (23 to $124 \mathrm{mg} /$ tiller; Table 6). Although tiller density declined across this range, the proportional decline in density was much less than the increase in tiller mass, resulting in a doubling or tripling of herbage mass as sward height increased (Table 6). Thus one likely mechanism for the often-observed response of increasing herbage accumulation with longer regrowth intervals (i.e., taller swards) is an increase in tiller mass. Sbrissia et al. (2003) suggested that there are limits to plasticity depending on grass species and growing environment. They indicated that during reproductive growth in April, a 5-cm grazing height was below the plasticity limit for Tifton 85, i.e., both tiller number and mass were lowest for the 5 - $\mathrm{cm}$ grazing height. Thus, during that time of year tiller mass/density compensation did not occur. This is likely associated with responses observed in other Cynodon studies where sustained close grazing negatively impacted sward persistence.

Sbrissia et al. (2001) conducted a similar tiller dynamics study with 'Coastcross' "bermudagrass”. Like Tifton 85, Coastcross is an interspecific hybrid between $C$. dactylon and C. nlemfuensis (Taliaferro et al., 2004). Results were similar to those reported for Tifton 85, with tiller mass/density compensation in operation for Coastcross during spring and summer. During autumn, however, pastures grazed to $5 \mathrm{~cm}$ were not able to compensate for lower tiller mass by increasing tiller density. Because this study was not repeated for a second year, it is not clear whether this response was strictly seasonal or in part due to cumulative stress associated with continuous stocking and low stubble height.

\section{Integration of Crop and Cynodon-Based Livestock Systems}

Agricultural systems that combined crop production with animal husbandry developed 8-10 thousand years ago (Franzluebbers, 2007). These systems produced varied products for mainly subsistence agriculture. They also used crop residues to feed ruminant animals and animal manures to enhance soil fertility. Agriculture in the industrialized countries in the last 60 years has become increasingly specialized in response to a range of political, regulatory, and economic forces (Russelle et al., 2007). As a consequence, crop production in many industrialized countries has become geographically separate from animal production, and this change has had a huge impact on agriculture and greatly affects risk management, sustainability, economics, and environmental impact (Franzluebbers, 2007).

Today, agriculture and agricultural scientists are faced with huge challenges about how the world and its people can be sustained. There is growing awareness that the stability and resiliency of agricultural landscapes are impaired by enterprise specialization, concentration of operations, and expansion of scale, which have spatially and temporally disrupted energy and nutrient cycles in a manner far removed from the natural ecosystem (Franzluebbers, 2007). More highly integrated crop and livestock enterprises are likely to a) more efficiently utilize natural resources, b) exploit natural pest control processes, c) reduce nutrient concentration and associated environment risk, and d) improve soil structure and productivity. Ruminant livestock are a critical component of this integration because of their ability to convert cellulosic feedstuffs from pastures and crop residues into high-value meat and milk products. In this section of the review, the benefits of integrated systems to soil, water, and system economics will be explored To the extent possible, the focus will be systems in which Cynodon forages play a major role.

\section{Soil Benefits}

Perennial grasslands are receiving increasing attention in the effort to sequester carbon because more than $95 \%$ of the carbon in grassland agroecosystems is found below ground, most occurring as soil organic carbon (Wedin, 2004). Warm-climate grasslands, though containing only $6 \%$ of global terrestrial biomass, contain approximately $15 \%$ of global soil organic carbon (Schlesinger, 1997; Jobbagy and Jackson, 2000). Temperate grasslands contribute another $7 \%$ for a total of $22 \%$ of global soil organic carbon in grasslands. It 
has been well established that agroecosystems including perennial forages accumulate soil organic carbon at a faster rate and to greater amounts than annual rowcropping systems (Fransleubbers, 2007). Perennial forages also place sequestered carbon deeper in the soil profile than annual crops (Fisher et al., 1994; Russelle et al., 2007).

Continuous annual row cropping is associated with low levels of soil organic carbon (Franzluebbers, 2007). Bermudagrass establishment on previously continuously cropped land resulted in an increase in soil organic carbon from 13 to $20 \mathrm{Mg} / \mathrm{ha}$ in 5 years (Franzluebbers et al., 2001). Rate of increase depended on management. Hayed, unharvested, and grazed bermudagrass swards had increases of $0.3,0.6$, and 1.4 tons carbon/ha/year. The authors attributed greater rate of increase on grazed pasture to fecal return directly on the paddock. In a companion study with bermudagrass, particulate organic carbon increased at a rate of 730 , 650,1360 , and $1400 \mathrm{~kg} / \mathrm{ha} /$ year for swards that were hayed, unharvested, or grazed at low or high grazing pressure (Franzluebbers and Stuedemann, 2003). The authors concluded that particulate and biologically active carbon pools increased under all bermudagrass management strategies, but cattle grazing resulted in the greatest increase partly because of the return of feces to soil.

Romkens et al. (1999) reported that depleted soil carbon stocks due to continuous cropping were $90 \%$ restored after 9 years of pasture. They noted that perennial grasses deposit carbon lower in the soil profile than annual crops and that this carbon is better "protected” from release. Inclusion of perennial grasses in cropping systems has resulted in increased soil organic carbon and this has been associated with improved soil tilth, water-holding capacity, nutrient supply, and grain yield potential (Russelle et al., 2007). Environmental benefits have also accrued due to rotations with perennial grasses. Estimates from models suggest that annual nitrogen load to streams in Iowa, USA could be decreased by $28 \%$ and leachable nitrogen decreased by $67 \%$ by integrating forages into rotations and replacing cropping on steep slopes with permanent pasture (Burkhart et al., 2005).

Soil fauna and microbial biomass also may benefit from integrating perennial grasses in cropping systems. Katsvairo et al. (2007) reported greater earthworm population in a Florida crop rotation including bahiagrass than with continuous row cropping. Bermudagrass swards were established in soils that had been row cropped for many years and were heavily eroded (Franzluebbers and Stuedemann, 2003). Swards were hayed, unharvested, or grazed at low or high grazing pressure. Soil microbial biomass carbon accumulation rate was 74, 51, 96, and 119 $\mathrm{kg} / \mathrm{ha} /$ year, respectively, for the four treatments. On average, bermudagrass establishment on eroded cropland resulted in accumulation of soil microbial biomass carbon at a rate of $19-24 \%$ per year with grazing compared to $10-15 \%$ without cattle grazing (Franzleubbers and Stuedemann, 2003).

\section{Water Quality Benefits}

There is a well-established body of literature confirming that inclusion of perennial forages in cropping systems minimizes potential for negative environmental impact of agriculture. This is due to the ability of forages to decrease soil erosion (Karlen et al., 2007), reduce particulates in surface water (Karlen et al., 2007), and minimize nutrient leaching through the root zone to ground water (Woodard et al., 2002).

The value of utilizing bermudagrass in a cropping system for dairy cattle was evaluated in Florida (Woodard et al., 2002). Two forage systems were compared. One was the traditional triple-crop system of maize (Zea mays), sorghum (Sorghum bicolor), and rye (Secale cereale) vs. an alternative system including bermudagrass and rye. Dairy wastewater was sprayed on the cropping systems to apply 500,690, and $910 \mathrm{~kg}$ nitrogen/ha/year in each of four years. The bermudagrass systems removed 465, 528, and $585 \mathrm{~kg}$ nitrogen/ha/year, while the annual row crop system removed 320, 327, and $378 \mathrm{~kg}$ nitrogen/ha/year. The bermudagrass system was much more efficient at preventing nitrate leaching to shallow soil water in part because of the continual presence of an active root system, unlike the annual system which required cycles of plant establishment each year.

Bermudagrass can also be used for phytoremediation efforts, i.e., to reduce high levels of a soil component. Phosphorus accumulation often occurs on sites that are highly impacted by livestock manures. Hybrid bermudagrasses can remove 50 to $60 \mathrm{~kg}$ phosphorus/ha/year depending on soil conditions and 
the growing environment (Brink et al., 2002). Rates of drawdown of soil phosphorus are thought to be greater than for a row crop like corn because of multiple hay harvests per year and removal of herbage to be fed at off-site locations for the forage system (McLaughlin et al., 2005).

\section{Economic Benefits}

Although data with Cynodons were not found in the literature, species adapted to comparable environments have been used to make economic comparisons between conventional row crop and integrated crop-livestock systems. An 80-ha conventional peanut (Arachis hypogea)-cotton (Gossypium sp.) system in Florida was compared with a system including bahiagrass rotation. Results showed that net profit per year was $\$ 15,700$ on the conventional farm, \$35,600 with hay harvest of bahiagrass, and $\$ 44,840$ with cattle grazing second-year bahiagrass (20 ha; Marois et al., 2002).

\section{For further consideration}

Sustainable grassland production systems are defined as those that over the long term enhance environmental quality and the resource base of the system while providing human food needs in an economically viable manner and improve the quality of life for both producers and consumers (Stewart et al., 1991). Achieving sustainability is becoming more and more difficult and requires new ways of thinking and new ways of going about our work in grassland research.

We are in the midst of a rapid transition from a period of cheap and readily available energy to one of high prices and perhaps soon, energy scarcity. This is occurring simultaneously with ballooning world population and demand for other limited resources, e.g., nutrients and water, as well as increasing evidence of the impact of climate change. Those of us who work in forage-livestock systems must take seriously the implications of these transitions and assess their longterm impact on the grassland agroecosystems we study. For example, it is unlikely that we will be able to sustain high input grassland agriculture or even markedly increase fertilizer and water inputs to low- input grasslands because these systems are a lower priority than cropland used to produce food for direct human consumption.

The Cynodon grasses have been important historically in forage-livestock production systems. As we think about sustainability of Cynodon- and other $\mathrm{C}_{4}$ grass-based systems, we must identify innovative ways of providing the nutrients that they will need. Fertilizers are likely to become increasingly uneconomical. Can new management strategies for legumes play a role? Perhaps, but that is unlikely to be a universal solution. The trend toward decoupling crop and livestock production systems needs to be reversed. Re-integrating these systems allows livestock manures to be cycled into crop production and insures that the soil fertility benefits that accrue from a grassland component of a rotation can be captured for production of crops. Thus as we think about future sustainability of Cynodons and other forage grasses, it is likely that those of us conducting this research will need to accept new challenges and address questions and possible solutions that we have not yet included in our research efforts.

\section{References}

Bardgett, R.D., and D.A. Wardle. 2003. Herbivore-mediated linkages between aboveground and belowground communities. Ecology 84:2258-2268.

Boddey, R.M., R.Macedo, R.M. Tarré, E. Ferreira, O.C. de Oliveira, C. de P. Rezende, R.B. Cantarutti, J.M. Pereira, B.J.R. Alves, S. Urquiaga. 2004. Nitrogen cycling in Brachiaria pastures: the key to understanding the process of pasture decline. Agric. Ecosyst. Env. 103:389-403.

Boddey, R.M., R.M. Tarré, R. Macedo, C. de P. Rezend, J.M. Pereira, B.J.R. Alves, and S. Urquiaga. 2005. Cycling of N and $\mathrm{P}$ in grass-alone (Brachiaria) and mixed grass-legume (Brachiaria-Desmodium ovalifolium) grazed pastures in the Atlantic forest region of Brazil. p. 58. In S.C. Jarvis et al. (ed.) Optimisation of nutrient cycling and soil quality for sustainable grasslands. Wageningen Academic Publishers, Wageningen, The Netherlands.

Brink, G.E., D.E. Rowe, and K.R. Sistani. 2002. Broiler litter application effects on yield and nutrient uptake of 'Alicia' bermudagrass. Agron. J. 94:911-916.

Bryan, W.B., E.C. Prigge, M. Lasat, T. Pasha, D.J. Flaherty, and J. Lozier. 2000. Productivity of Kentucky bluegrass pasture grazed at three heights and two intensities. Agron. J. 92:3035.

Burkhart, M. D. James, M. Liebman, and C. Herndl. 2005. Impacts of integrated crop-livestock systems on nitrogen dynamics and soil erosion in western Iowa watersheds. J. Geophys. Res. 110:G01009, doi:10.1029/2004JG000008. 
Burton, G.W., and W.G. Monson. 1984. Registration of 'Tifton 68' bermudagrass. Crop Sci. 24:1211.

Burton, G.W., and E.H. DeVane. 1992. Growing legumes with 'Coastal' bermudagrass in the Lower Coastal Plain. J. Prod. Agric. 5:278-281.

Castilla, C.E., M.A. Ayarza, and P.A. Sanchez. 1995. Carbon and potassium dynamics in grass/legume grazing systems in the Amazon. p. 191-210. In J. M. Powell (ed.) Livestock and sustainable nutrient cycling in mixed farming systems of subSaharan Africa, Vol. 2. ILCA, Addis Ababa, Ethiopia.

Caro-Costas, R., F. Abruna, and J. Vicente-Chandler. 1972. Comparison of heavily fertilized pangola and stargrass pastures in terms of beef production and carrying capacity in the humid mountain region of Puerto Rico. J. Agric. Univ. P.R. 56:104-110.

Chacon, E., and T.H. Stobbs. 1976. Influence of progressive defoliation of a grass sward on the eating behaviour of cattle. Aust. J. Agric. Res. 27:709-727.

Chapman, D.F., and G. Lemaire. 1993. Morphogenetic and structural determinants of plant growth after defoliation. p. 55-64. In M.J. Baker (ed.) Grasslands for our world. SIR Publishing, Wellington, New Zealand.

Chapman, D.F., A.J. Parsons, G.P. Cosgrove, D.J. Barker, D.M. Marotti, K.J. Venning, S.M. Rutter, J. Hill, and A.N. Thompson. 2007. Impacts of spatial patterns in pasture on animal grazing behavior, intake, and performance. Crop Sci. 47:399-415.

Dubeux, J.C.B., Jr., L.E. Sollenberger, B.W. Mathews, J.M. Scholberg, and H.Q. Santos. 2007. Nutrient cycling in warmclimate grasslands. Crop Sci. 47:915-928.

Dubeux, J.C.B., Jr., L.E. Sollenberger, J.M.B. Vendramini, R.L. Stewart Jr., and S.M. Interrante. 2006a. Litter mass, deposition rate, and chemical composition in bahiagrass pastures managed at different intensities. Crop Sci. 46:12991304.

Dubeux, J.C.B., Jr., L.E. Sollenberger, S.M. Interrante, J.M.B. Vendramini, and R.L. Stewart, Jr. 2006b. Litter decomposition and mineralization in bahiagrass pastures managed at different intensities. Crop Sci. 46:1305-1310.

Fisher, M.J., I.M. Rao, M.A. Ayarza, C.E. Lascano, J.I. Sanz, R.J. Thomas, and R.R. Vera. 1994. Carbon storage by introduced deep-rooted grasses in the South American savannas. Nature 371:236-238.

Fisher, M.J., I.M. Rao, and R.J. Thomas. 1997. Nutrient cycling in tropical pastures, with special reference to the neotropical savannas. p. 371-382. In J.G. Buchanan-Smith et al. (ed.). Int. Grassl. Cong., 18th, Winnipeg and Saskatoon, Canada. 8-17 June 1997. Canadian Grassl. Soc., Winnipeg.

Forage and Grazing Terminology Committee (FGTC). 1992. Terminology for grazing lands and grazing animals. J. Prod. Agric. 5:191-201.

Franzluebbers, A.J. 2007. Integrated crop-livestock systems in the southeastern USA. Agron. J. 99:361-372.

Franzluebbers, A.J., and J.A. Stuedemann. 2003. Bermudagrass management in the southern Piedmont USA. III. Particulate and biologically active soil carbon. Soil Sci. Soc. Am. J. 67:132-138.
Franzluebbers, A.J., J.A. Stuedemann, and S.R. Wilkinson. 2001. Bermudagrass management in the southern Piedmont USA: I. Soil and surface residue carbon and sulfur. Soil Sci. Soc. Am. J. 65:834-841.

Harlan, J.R. 1970. Cynodon species and their value for grazing and hay. Herb. Abstr. 40:233-238.

Hernández Garay, A., L.E. Sollenberger, D.C. McDonald, G.J. Ruegsegger, R.S. Kalmbacher, and P. Mislevy. 2004a. Nitrogen fertilization and stocking rate affect stargrass pasture and cattle performance. Crop Sci. 44:1348-1354.

Hernández Garay, A., L.E. Sollenberger, C.R. Staples, and C.G.S. Pedreira. 2004b. Florigraze and Arbrook rhizoma peanut as pasture for growing Holstein heifers. Crop Sci. 44:1355-1360.

Humphreys, L.R. 1991. Tropical pasture utilization. Cambridge Univ. Press, Cambridge, UK.

Jobbagy, E.G., and R.B. Jackson. 2000. The vertical distribution of soil organic carbon and its relation to climate and vegetation. Ecol. Applic. 10: 423-436.

Jones, R.J., and R.M. Jones. 1997. Grazing management in the tropics. p. 535-542. In Proc. Int. Grassl. Congr., 18th, Winnipeg and Saskatoon, Canada. 8-17 June 1997. Grasslands 2000, Toronto.

Karlen, D.L., J.L. Lemunyon, and J.W. Singer. 2007. Forages for conservation and improved soil quality. p. 149-166. In R.F Barnes et al. (ed.) Forages: the science of grassland agriculture. Blackwell Publishing, Oxford, UK.

Katsvairo, T.W., D.L. Wright, J.J. Marois, D.L. Hartzog, K.B. Balkcom, P.P. Wiatrak, and J.R. Rich. 2007. Cotton roots, earthworms, and infiltration characteristics in sod-peanutcotton cropping systems. Agron. J. 99:390-398.

Kretschmer, A.E., Jr., and W.D. Pitman. 2001. Germplasm resources of tropical forage legumes. p. 41-57. In A. Sotomayor-Rios and W.D. Pitman (ed.) Tropical forage plants: Development and use. CRC Press, New York.

Liu, K., L.E. Sollenberger, U.R. White, Y.C. Newman, and J.M.B. Vendramini. 2008. Grazing intensity and frequency effects on herbage accumulation and nutritive value of Tifton 85 bermudagrass (Cynodon spp.). Proc. of 21st Int. Grassl. Cong. (in press).

Mandebvu, P., J.W. West, G.M. Hill, R.N. Gates, R.D. Hatfield, B.G. Mullinix, A.H. Parks, and A.B. Caudle. 1999. Comparison of Tifton 85 and Coastal bermudagrasses for yield, nutrient traits, intake, and digestion by growing beef steers. J. Anim. Sci. 77:1572-1586.

Marois, J.J., D.L. Wright, J.A. Baldwin, and D.L. Hartzog. 2002. A multi-state project to sustain peanut and cotton yields by incorporating cattle in a sod-based rotation. p. 101-107. In E. van Santen (ed.) Proc. 25th Ann. South. Conserv. Tillage Conf. Sustain. Agric., Auburn, AL. 24-26 June 2002. Alabama Agric. Exp. Stn. and Auburn Univ.

Matches, A.G. 1992. Plant response to grazing: a review. J. Prod. Agric. 5:1-7.

Mathews, B.W., S.C. Miyasaka, and J.P. Tritschler. 2004. Mineral nutrition of C4 forage grasses. p. 217-266. In L. E. Moser et al. (ed.) Warm-season (C4) Grasses. ASA/CSSA/SSSA, Madison, WI.

Mathews, B.W., L.E. Sollenberger, W.E. Kunkle, J.E. Moore, and A.C. Hammond. 1994. Dairy heifer and bermudagrass pasture responses to rotational and continuous stocking. J. Dairy Sci. 77:244-252. 
Matthew, C., G. Lemaire, N.R. Sackville Hamilton, and A. Hernandez Garay. 1995. A modified self-thinning equation to describe size/density relationships for defoliated swards. Ann. Bot. 76:579-587.

McLaughlin, M.R., K.R. Sistani, T.E. Fairbrother, and D.E. Rowe. 2005. Overseeding common bermudagrass with coolseason annuals to increase yield and nitrogen and phosphorus uptake in a hay field fertilized with swine effluent. Agron. J. 97:487-493.

Mislevy, P., and F.G. Martin. 1998. Comparison of Tifton 85 and other Cynodon grasses for production and nutritive value under grazing. Soil Crop Sci. Soc. Florida Proc. 57:77-82.

Mislevy, P., F.G. Martin, B.J. Downs, and K.L. Singer. 1989. Response of stargrass to grazing management. Proc. Int. Grassl. Cong., 16th. p. 1017-1018. In R. Desroches (ed.) Proc. Int. Grassl. Congress, 16th, Nice, France. 4-11 Oct. 1989. The French Grassland Society, Versailles Cedex, France.

Mullen, B.F., H.M. Shelton, and S.A. Dalzell. 2005. Leucaena in northern Australia: a tropical forage legume success story. p. 333. In F.P. O'Mara et al. (ed.) Proc. Int. Grassl. Cong. 20th, Dublin, Ireland, 26 June-2 July 2005. Wageningen Academic Publishers, Wageningen, The Netherlands.

Myers, R.J.K., I. Vallis, W.B. McGill, and E.F. Henzell. 1986. Nitrogen in grass-dominant, unfertilized pasture systems. p. 761-771. Int. Soc. Soil Sci. Cong., 13th, vol. 6, 13-20 Aug. 1986. Hamburg, Germany.

Newman, Y.C., L.E. Sollenberger, W.E. Kunkle, and C.G. Chambliss. 2002. Canopy height and nitrogen supplementation effects on performance of heifers grazing limpograss. Agron. J. 94:1375-1380.

Ortega-S., J.A., L.E. Sollenberger, J.M. Bennett, and J.A. Cornell. 1992. Rhizome characteristics and canopy light interception of grazed rhizoma peanut pastures. Agron. J. 84:804-809.

Parsons, A.J., I.R. Johnson, and A. Harvey. 1988. Use of a model to optimize the interaction between frequency and severity of intermittent defoliation and to provide a fundamental comparison of the continuous and intermittent defoliation of grass. Grass Forage Sci. 43:49-59.

Pedreira, C.G.S., L.E. Sollenberger, and P. Mislevy. 1999. Productivity and nutritive value of 'Florakirk' bermudagrass as affected by grazing management. Agron. J. 91:796-801.

Pedreira, C.G.S., L.E. Sollenberger, and P. Mislevy. 2000. Botanical composition, light interception, and carbohydrate reserve status of grazed 'Florakirk' bermudagrass. Agron. J. 92:194-199.

Pengelly, B.C., A. Whitbread, P.R. Mazaiwana, and N. Mukombe. 2003. Tropical forage research for the future better use of research resources to deliver adoption and benefits to farmers. Trop. Grassl. 37:207-216.

Peters, M., and C.E. Lascano. 2003. Forage technology adoption: linking on-station research with participatory methods. Trop. Grassl. 37:197-203.

Pitman, W.D. 1991. Management of stargrass pastures for growing cattle using visual pasture characteristics. Fla. Agric. Exp. Stn. Bull. 884.
Premazzi, L.M., F.A. Monteiro, and J.E. Corrente. 2003. Tillering of Tifton 85 bermudagrass in response to nitrogen rates and time of application after cutting. Scientia Agricola 60:565-571.

Prine, G.M., and G.W. Burton. 1956. The effect of nitrogen rate and clipping frequency upon the yield, protein content and certain morphological characteristics of Coastal bermudagrass (Cynodon dactylon, (L.) Pers.). Agron J. 48:296-301.

Redfearn, D.D., and C.J. Nelson. 2003. Grasses for southern areas. p. 149-169. In R.F. Barnes et al. (ed.) Forages: An introduction to grassland agriculture. Iowa State Press, Ames, IA.

Reis, R.A., L.E. Sollenberger, and D. Urbano. 2001. Impact of overseeding cool-season annual forages on spring regrowth of Tifton 85 bermudagrass. p. 295-297. In J.A. Gomide et al. (ed.) Proc. Int. Grassl. Cong., 19th, Piracicaba, Brazil, 10-21 Feb. 2001. Brazilian Society of Animal Husbandry, Piracicaba, Brazil.

Rezende, C.P., R.B. Cantarutti, J.M. Braga, J.A. Gomide, E. Ferreira, R. Tarré, R. Macedo, B.J.R. Alves, S. Urquiaga, G. Cadisch, K.E. Giller, and R.M. Boddey. 1999. Litter deposition and disappearance in Brachiaria pastures in the Atlantic forest region of the South of Bahia, Brazil. Nutr. Cycl. Agroecosyst. 54:99-112.

Robertson, F.A., R.J.K. Myers, and P.G. Saffigna. 1993a. Carbon and nitrogen mineralization in cultivated and grassland soils in subtropical Queensland. Aust. J. Soil Res. 31:611-619.

Römkens, P.F.A.M., J.van der Pflicht, and J. Hassink. 1999. Soil organic matter dynamics after the conversion of arable land to pasture. Biol. Fertil. Soils 28:277-284.

Rotz, C.A., F. Taube, M.P. Russelle, J. Oenema, M.A. Sanderson, and M. Wachendorf. 2005. Whole-farm perspectives of nutrient flows in grassland agriculture. Crop Sci. 45:2139-2159.

Russelle, M.P., M.H. Entz, and A.J. Franzluebbers. 2007. Reconsidering integrated crop-livestock systems in North America. Agron. J. 99:325-334.

Rutter, S.M., K.L. Young, J.E. Cook, and R.A. Champion. 2003. Strip grazing separate white clover and ryegrass monocultures increases daily intake and milk yield in dairy cows. Trop. Subtrop. Agroecosyst. 3:461-465.

Sbrissia, A.F., S.C. da Silva, C.A.B. de Carvalho, R.A. Carnevalli, L.F. de Moura Pinto, J.L. Fagundes, and C.G.S. Pedreira. 2001. Tiller size/population density compensation in grazed Coastcross bermudagrass swards. Scientia Agricola 58:655-665.

Sbrissia, A.F., S.C. da Silva, C. Mathew, C.A.B. de Carvalho, R.A. Carnevalli, L.F. de Moura Pinto, J.L. Fagundes, and C.G.S. Pedreira. 2003. Tiller size/density compensation in grazed Tifton 85 bermudagrass swards. Pesq. Agropec. Bras. 38:1459-1468.

Schlesinger, W.H. 1997. Biogeochemistry: An analysis of global change. Academic Press, San Diego, CA.

Shelton, H.M., S. Franzel, and M. Peters. 2005. Adoption of tropical legume technology around the world: analysis of success. p. 149-166. In D.A. McGilloway (ed.) Grassland: a global resource. Wageningen Academic Publishers, Wageningen, The Netherlands.

Sollenberger, L.E., and M. Collins. 2003. Legumes for southern areas. p. 191-213. In R.F Barnes, C.J. Nelson, M. Collins, 
and K.J. Moore (ed.) Forages, Volume 1 - An introduction to grassland agriculture, Iowa State Univ. Press, Ames, IA.

Stewart, B.A., and R. Lal, and S.A. El-Swaify. 1991. Sustaining the resource base of an expanding world agriculture. p. 125144. In R. Lal and F.J. Pierce (ed.) Soil management for sustainability. Soil \& Water Conservation Society, Ankeny, IA.

Stringer, W.C., A. Khalilian, D.J. Undersander, G.S. Stapleton, and W.C. Bridges, Jr. 1994. Row spacing and nitrogen: Effect on alfalfa-bermudagrass yield and botanical composition. Agron. J. 86:72-76.

Taliaferro, C.M., F.M. Rouquette, Jr., and P. Mislevy. 2004. Bermudagrass and stargrass. p. 417-475. In L.E. Moser et al. (ed.) Warm-season (C4) grasses. ASA/CSSA/SSSA, Madison, WI.

Thomas, R.J. 1992. The role of the legume in the nitrogen cycle of productive and sustainable pastures. Grass For. Sci. 47:133-142.

Thomas, R.J., and N.M. Asakawa. 1993. Decomposition of leaf litter from tropical grasses and legumes. Soil Biol. Biochem. 25:1351-1361.

Valentim, J.F., and C.M.S. Andrade. 2005. Forage peanut (Arachis pintoi): a high yielding and high quality legume for sustainable cattle production systems in the Western Brazilian Amazon. p. 329. In F.P. O’Mara et al. (ed.) Proc. Int. Grassl. Cong. 20th, Dublin, Ireland, 26 June-2 July 2005. Wageningen Academic Publishers, Wageningen, The Netherlands.
Vendramini, J.M.B., L.E. Sollenberger, A.T. Adesogan, J.C.B. Dubeux, Jr., S.M. Interrante, R.L. Stewart, Jr., and J.D. Arthington. 2008. Protein fractions of Tifton 85 and ryeryegrass due to sward management practices. Agron. J. 100:463-469.

Vendramini, J.M.B., L.E. Sollenberger, J.C.B. Dubeux, Jr., S.M. Interrante, R.L. Stewart, Jr., and J.D. Arthington. Sward management effects on forage component responses in a production system for early-weaned calves. Agron. J. (in review).

Walker, J.W. 1995. Viewpoint: Grazing management and research now and in the next millenium. J. Range Manage. 48:350-357.

Wedin, D.A. 2004. C4 Grasses: Resource use, ecology, and global change. p. 15-50. In L.E. Moser et al. (ed.) Warmseason (C4) grasses. ASA/CSSA/SSSA, Madison, WI.

Wedin, D.A., and M.P. Russelle. 2007. Nutrient cycling in forage production systems. p. 137-148. In R.F. Barnes et al. (ed.) Forages: The science of grassland agriculture. Blackwell Publishing, Ames, IA.

Woodard, K.R., E.C. French, L.A. Sweat, D.A. Graetz, L.E. Sollenberger, B. Macoon, K.M. Portier, B.L. Wade, S.J. Rymph, G.M. Prine, and H.H. Van Horn. 2002. Nitrogen removal and nitrate-N leaching for forage systems receiving dairy effluent. J. Environ. Qual. 31:1980-1992.

Zarate, P., A.J. Saldivar, W.R. Ocumpaugh, W.H. Hamilton, A. Martinez, and H. Diaz. 2004. Overseeding Desmanthus on Tifton 68 bermudagrass. p. 256-260. In American Forage Grassl. Coun. Proc. 12-16 June 2004, Roanoke, VA. 
Table 1. Stocking rate $X N$ fertilizer rate interaction means for crude protein concentration of hand-plucked stargrass herbage in Jamaica. Data are means across 2 years and two replicates $(n=4)$. Adapted from Hernández Garay et al. $(2004 a)$.

\begin{tabular}{|c|c|c|c|c|}
\hline \multirow{2}{*}{$\begin{array}{c}\text { Stocking } \\
\text { rate }\end{array}$} & \multicolumn{3}{|c|}{$\mathrm{N}$ rate $\left(\mathrm{kg} \mathrm{ha}^{-1}\right)$} & \multirow[t]{2}{*}{ Polynomial contrasts $^{\dagger}$} \\
\hline & 112 & 224 & 336 & \\
\hline & head ha ${ }^{-1}$ & \multicolumn{2}{|c|}{ 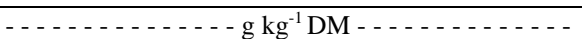 } & \\
\hline 5.0 & 125 & 145 & 149 & $\mathrm{~L}^{* *}, \mathrm{Q}^{*}$ \\
\hline 7.5 & 150 & 151 & 152 & NS \\
\hline SEM & 2.6 & 2.6 & 2.6 & \\
\hline Polynomial contrasts $^{\dagger}$ & $\mathrm{L}^{* *}$ & $\mathrm{~L}^{* *}$ & $\mathrm{~L}^{* *}$ & \\
\hline
\end{tabular}

**, *, and NS $=\mathrm{P}<0.01, \mathrm{P}<0.05$, and $\mathrm{P}>0.05$, respectively.

$\mathrm{TL}=$ linear and $\mathrm{Q}=$ quadratic effect of stocking rate or $\mathrm{N}$ rate.

Table 2. Stocking rate $X N$ fertilizer rate interaction means for in vitro digestible organic matter concentration of hand-plucked stargrass herbage in Jamaica. Data are means across 2 years and two replicates $(n=4)$. Adapted from Hernández Garay et al. (2004a).

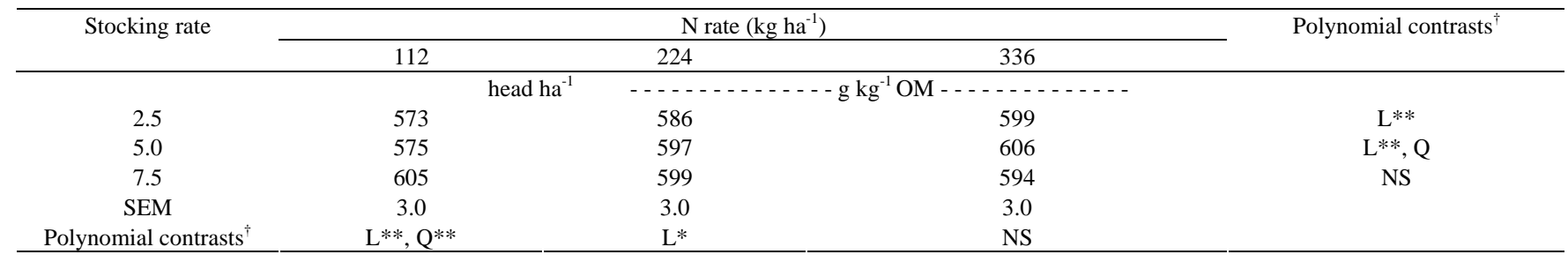

** ${ }^{*}$, and NS $=\mathrm{P}<0.01, \mathrm{P}<0.05$, and $\mathrm{P}>0.10$, respectively.

$\mathrm{TL}=$ linear and $\mathrm{Q}=$ quadratic effect of stocking rate or $\mathrm{N}$ rate. $\mathrm{Q}$ with no asterisk, $\mathrm{P}<0.10$.

Table 3. Average herbage accumulation of four Cynodon grasses to interval between grazing events. Post-graze stubble height was from 8-12 cm, and data are adapted from Mislevy and Martin (1998).

\begin{tabular}{|c|c|c|c|c|}
\hline \multirow{3}{*}{ Year } & \multicolumn{3}{|c|}{ Grazing interval (weeks) } & \multirow{3}{*}{ Polynomial contrast } \\
\hline & 2 & 4 & 6 & \\
\hline & \multicolumn{3}{|c|}{ (- - - - - - - - - - tons/ha - - - - - - - - - - } & \\
\hline 1 & $11.5^{\dagger}$ & 13.1 & 14.8 & Linear \\
\hline 3 & 6.2 & 10.5 & 14.8 & Linear \\
\hline
\end{tabular}

${ }^{\dagger}$ Data presented are predicted values from equations provided by Mislevy and Martin (1998).

Table 4. Effect of grazing method on animal gain, forage in vitro digestibility, and change in botanical composition of Callie bermudagrass pastures in Florida. Data are adapted from Mathews et al. (1994).

\begin{tabular}{|c|c|c|c|c|}
\hline $\begin{array}{c}\text { Grazing } \\
\text { method } \dagger\end{array}$ & $\begin{array}{c}\text { Average daily gain - Year 1 } \\
(\mathrm{kg})\end{array}$ & $\begin{array}{c}\text { Average daily gain - Year 2 (kg) } \\
\text { Rotational:short }\end{array} \quad 0.42 \mathrm{a} \ddagger$ & $0.50 \mathrm{a}$ & $\begin{array}{c}\text { In vitro digestibility } \\
(\mathrm{g} / \mathrm{kg})\end{array}$ \\
\hline Rotational:Iong & $0.45 \mathrm{a}$ & $0.51 \mathrm{a}$ & $577 \mathrm{a}$ \\
\hline Continuous & $0.58 \mathrm{~b}$ & $0.49 \mathrm{a}$ & $574 \mathrm{ab}$ & -4 \\
\hline
\end{tabular}

${ }^{\dagger}$ Rotational:short = rotational stocking with 15 paddocks and short grazing periods, postgraze stubble of $15 \mathrm{~cm}$; rotational:long = rotational stocking with 3 paddocks and longer grazing periods, postgraze stubble of $15 \mathrm{~cm}$; and continuous = continuous stocking at the same stocking rate as rotational long.

${ }^{\ddagger}$ Means within a column followed by the same letter are not different $(P<0.10)$. 
Table 5. Tifton 85 bermudagrass herbage accumulation response to intensity and frequency of grazing in Florida. Adapted from Liu et al. (2008).

\begin{tabular}{|c|c|c|c|c|}
\hline \multirow{2}{*}{ Stubble height $(\mathrm{cm})$} & \multicolumn{3}{|c|}{ Regrowth period (days) } & \multirow{2}{*}{ Polynomial contrast $^{\dagger}$} \\
\cline { 2 - 5 } & 14 & 21 & 28 & \\
\hline & & 21 & 15.4 & L,Q \\
\hline 8 & 11.4 & 11.3 & 14.5 & L,Q \\
\hline 24 & 13.1 & 11.0 & 11.9 & NS \\
\hline Polynomial contrast ${ }^{\dagger}$ & 14.2 & 12.8 & $\mathrm{~L}$ & \\
\hline
\end{tabular}

${ }^{\dagger} \mathrm{L}=$ linear; $\mathrm{Q}=$ quadratic; NS, $P>0.10$

Table 6. Tiller population density and mass and herbage mass of continuously stocked Tifton 85 bermudagrass swards grazed to maintain various sward surface heights. Data are adapted from Sbrissia et al. (2003).

\begin{tabular}{|c|c|c|c|c|c|}
\hline \multirow[t]{2}{*}{ Month } & \multicolumn{4}{|c|}{ Sward surface height $(\mathrm{cm})$} & \multirow[t]{2}{*}{ Significance level } \\
\hline & 5 & 10 & 15 & 20 & \\
\hline & \multicolumn{4}{|c|}{ Tiller population density (1000 tillers $\left./ \mathrm{m}^{2}\right)$} & \\
\hline Dec. & 16.3 & 13.4 & 8.9 & 7.2 & * \\
\hline Jan. & 17.7 & 14.9 & 14.2 & 13.6 & ns \\
\hline Apr. & 10.9 & 17.4 & 16.3 & 13.8 & $*$ \\
\hline \multirow[t]{2}{*}{ July } & 18.8 & 9.3 & 13.4 & 21.3 & ns \\
\hline & \multicolumn{4}{|c|}{ Tiller mass (mg/tiller) } & \\
\hline Dec. & 22 & 41 & 85 & 124 & ** \\
\hline Jan. & 12 & 27 & 36 & 55 & ** \\
\hline Apr. & 20 & 26 & 35 & 60 & $*$ \\
\hline \multirow[t]{2}{*}{ July } & 21 & 52 & 53 & 68 & ns \\
\hline & \multicolumn{4}{|c|}{ Herbage mass $\left(\mathrm{kg} / \mathrm{m}^{2}\right)$} & \\
\hline Dec. & 0.37 & 0.51 & 0.68 & 0.84 & $* * *$ \\
\hline Jan. & 0.20 & 0.37 & 0.48 & 0.66 & $* * *$ \\
\hline Apr. & 0.21 & 0.42 & 0.53 & 0.75 & $* * *$ \\
\hline Dec. & 0.37 & 0.46 & 0.62 & 0.79 & ** \\
\hline
\end{tabular}
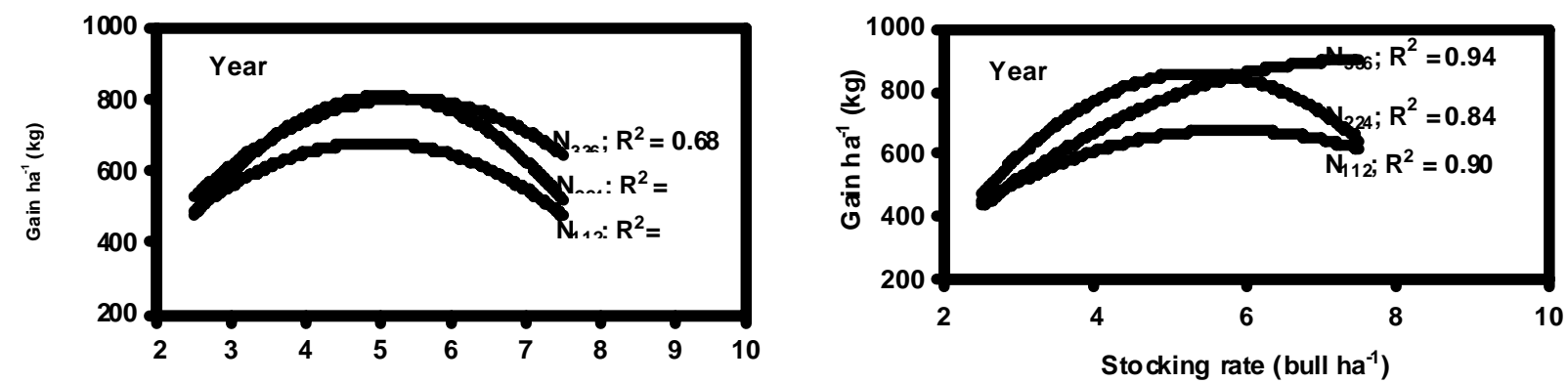

Figure 1. Weanling bull live weight gain ha $\mathrm{ha}^{-1}$ response to stocking rate (SR) on stargrass pastures fertilized at three rates of $\mathrm{N}$. For $\mathrm{N}$ rates of 112,224 , and $336 \mathrm{~kg} \mathrm{~N}^{-1}$, respectively, fitted curves for Year 1 are $\mathrm{Y}=-78+305 \mathrm{SR}-30.8 \mathrm{SR}^{2} ; \mathrm{Y}=-462+$ $499 \mathrm{SR}-49 \mathrm{SR}^{2}$; and $\mathrm{Y}=-160+359 \mathrm{SR}-33.5 \mathrm{SR}^{2}$. For $\mathrm{N}$ rates of 112,224 , and $336 \mathrm{~kg} \mathrm{~N}$ ha ${ }^{-1}$, respectively, fitted curves for Year 2 are $Y=-26+242 S R-20.8 S R^{2} ; Y=-488+501 S R-46.7 S R^{2}$; and $Y=-158+283 S R-19 S R^{2}$. Data are adapted from Hernández Garay et al. (2004a). 

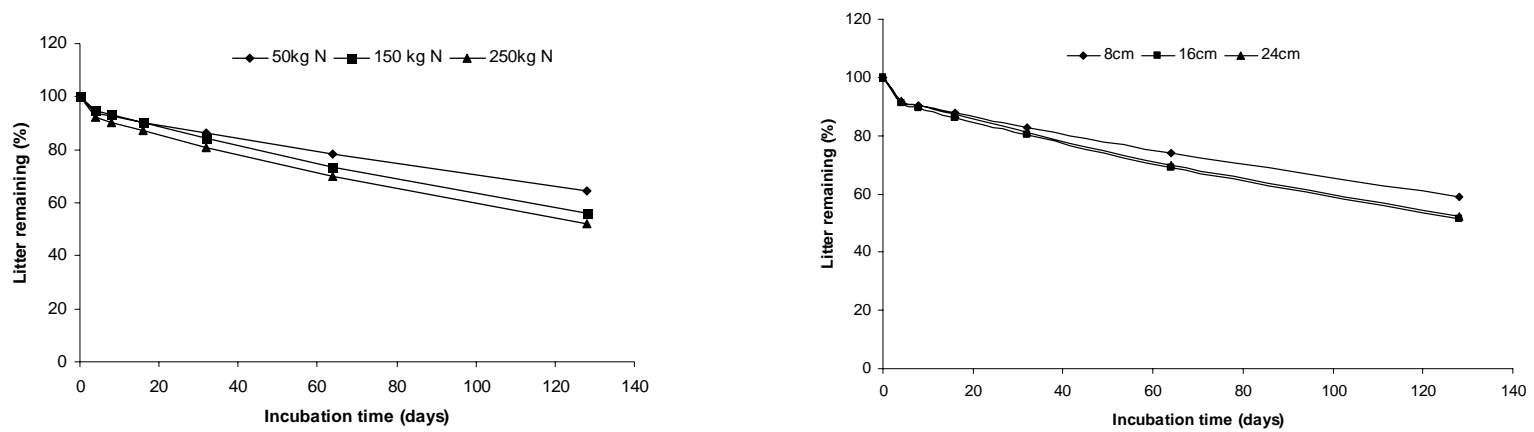

Fig. 2. Effect of nitrogen fertilization (top) and post-graze stubble height (bottom) of bermudagrass pastures on litter dry matter remaining following periods of field incubation in litter bags. After 128-day incubation period: $50 \mathrm{~kg}$ nitrogen/ha $>150 \mathrm{~kg}$ nitrogen/ha $>250 \mathrm{~kg}$ nitrogen/ha; 8-cm stubble > 16-cm stubble which was not different from 24-cm stubble. Data from K. Liu et al. (unpublished). 